\title{
Genetic Analysis of the Mycobacillin Biosynthetic Pathway in Bacillus subtilis $\mathbf{B}_{3}$
}

\author{
By SEKHAR MAJUMDER, NISHIT K. MUKHOPADHYAY, \\ SUBRATA K. GHOSH AND SUSIL K. BOSE* \\ Department of Biochemistry, University College of Science, 35 Ballygunge Circular Road, \\ Calcutta 700 019, India
}

(Received 29 December 1987)

\begin{abstract}
Twelve mycobacillin-negative $\left(\mathrm{My}^{-}\right)$mutants of Bacillus subtilis $\mathbf{B}_{3}$ were isolated from an auxotrophically tagged mycobacillin producer organism. In whole-cell fermentations of some of these $\mathrm{My}^{-}$mutants a penta- and a nonapeptide accumulated; these peptides were also obtained in a cell-free system in which a new tripeptide was also detected. The amino acid composition, $\mathrm{N}$ - and $\mathrm{C}$-terminal residues and amino acid sequence of these peptides agreed with those of equivalent segments of the mycobacillin molecule. The mycobacillin-synthesizing enzyme can be divided into three fractions that catalyse different steps in biosynthesis, and the defective enzyme fractions in the various mutant strains were identified by reconstitution experiments in vitro. The defects were further pin-pointed in mutant enzyme fractions by an ATP $\rightleftharpoons P_{i}$ exchange reaction and also by cell-free synthesis involving the use of membrane-bound enzyme. The defects so identified indicated the formation of tri-, penta- and nonapeptides as intermediates in the mycobacillin biosynthetic pathway.
\end{abstract}

\section{INTRODUCTION}

In the course of our work on the biosynthesis of mycobacillin by the gene-block technique, we reported the isolation, from whole-cell fermentation broth of mycobacillin-negative mutants, of an intermediate pentapeptide $\mathrm{Pro} \rightarrow \mathrm{Asp} \rightarrow \mathrm{Glu} \rightarrow \mathrm{Tyr} \rightarrow \mathrm{Asp}$. The role of this pentapeptide in the biosynthesis of mycobacillin was further confirmed by its production by a cell-free synthesizing system developed from these blocked mutants (Majumder et al., 1985). Although antibioticnegative mutants have been used in cell-free systems for the isolation of a dipeptide intermediate from gramicidin-S-negative mutants (Kambe et al., 1974) and to elucidate the role played by 4phosphopantetheine in peptide chain elongation (Hori et al., 1981), there appears to be no report of the use of antibiotic-negative mutants for accumulation studies in whole-cell fermentations to elucidate the biosynthetic pathways of any of the bioactive peptides (gramicidin S, tyrocidin, bacitracin, etc.). It might be that the biogenesis of mycobacillin differs from that of gramicidin $S$ and tyrocidin in many important details. Most of the bioactive peptides are synthesized in a concerted fashion whereby amino acids are individually activated by an $\mathrm{ATP} \rightleftharpoons \mathrm{PP}_{\mathrm{i}}$ exchange reaction (Itoh et al., 1968) and their intermediates remain covalently bound to the enzyme bed (Bredesen et al., 1969), the antibiotic being released upon completion of the molecule. The biogenesis of mycobacillin is a three-stage process (Ghosh et al., 1985). Each stage is initiated by a specific compound (amino acid or peptide) activated sequentially by an $A T P \rightleftharpoons P_{i}$ exchange reaction (Ghosh et al., 1985) and the incomplete intermediates of each stage probably remain non-covalently bound (Mukhopadhyay et al., 1986) to the enzyme fraction until the final product of the particular stage has been made, when it is released (Ghosh et al., 1985). Hence the behaviour of mycobacillin-negative mutants in whole-cell fermentation may differ from that of gramicidin $S$ and tyrocidin-negative mutants. The construction of a complete metabolic 
pathway depicting the entire sequence would necessitate the identification of more intermediate peptides in addition to the pentapeptide already isolated (Majumder et al., 1985) and we have, in the present work, attempted to do this using the gene-block technique.

\section{METHODS}

Organism and media. An arginine-requiring derivative, designated A-1, of the mycobacillin-producing Bacillus subtilis strain $\mathrm{B}_{3}$ was used (Majumder et al., 1985). The media used for isolation of mycobacillin-negative (My $\left.{ }^{-}\right)$ mutants (complex medium) and for isolation of peptides from culture broths (synthetic medium) were described by Majumder et al. (1985).

Isolation and characterization of $\mathrm{My}^{-}$mutants. The $\mathrm{My}^{-}$mutants were isolated by the method of Banerjee \& Bose (1964) and were further characterized with regard to $\mathrm{My}^{-}$and sporulation phenotype as described by Majumder $e t$ al. (1985).

Fermentation experiments. These experiments were carried out using a synthetic medium as described previously (Majumder et al., 1985) and peptides were characterized in respect of amino acid composition, C-and N-terminal residues, molecular mass and sequence as reported earlier (Majumder et al., 1985).

Cell-free synthesis and in vitro reconstitution experiments. These were done as described by Majumder et al. (1985).

Location of enzymic defects by $A T P \rightleftharpoons P_{\mathrm{i}}$ exchange. The exchange was studied following the method of Stulberg \& Novelli (1962) as described by Ghosh et al. (1983). The ATP $\rightleftharpoons P_{i}$ exchange reaction, dependent on mycobacillin amino acids added in a sequential manner and catalysed by the three enzyme fractions of wild and mutant strains, was done by the method of Ghosh et al. (1985). The asays were carried out by incubating a mixture of $50 \mu \mathrm{g}$ each of the enzyme fractions $\mathrm{A}, \mathrm{B}$ and $\mathrm{C}$ in $0.1 \mathrm{M}$-Tris/HCl buffer pH 8.0, $3 \mathrm{~mm}-\mathrm{ATP}, 5 \mathrm{~mm}-\mathrm{MgCl}_{2}, 10 \mathrm{~mm}-\mathrm{KF}, 2 \mathrm{mM}-$ dithiothreitol. Amino acids and $\mathrm{Na}_{2} \mathrm{H}^{32} \mathrm{PO}_{4}\left(10 \mu \mathrm{Ci}\right.$; sp. act. $\left.10 \mathrm{Ci} \mathrm{mol}{ }^{-1}, 370 \mathrm{GBq} \mathrm{mol}^{-1}\right)$ were added at concentrations of $5 \mathrm{mM}$ and $2 \mathrm{mM}$ respectively. The incubation was for $30 \mathrm{~min}$ at $30^{\circ} \mathrm{C}$ in a final volume of $300 \mu \mathrm{l}$. Incorporation of radioactivity into ATP was determined as previously described (Ghosh et al., 1983).

Location of enzymic lesions in different defective enzyme fractions by cell-free synthesis using a membrane-bound form of the enzyme. The membrane-bound (particulate) enzyme was prepared by the method of Mukhopadhyay $e t$ al. (1985). The sonicated extracts of wild and mutant strains that had been grown for $72 \mathrm{~h}$ were centrifuged first at $3000 \mathrm{~g}$ for $10 \mathrm{~min}$ and then again at $10000 \mathrm{~g}$ for $30 \mathrm{~min}$ to get the light pellet. The light pellet was further purified first by centrifugation at $10000 \mathrm{~g}$ in $50 \mathrm{mM}$-Tris/ $\mathrm{HCl}$ buffer $(\mathrm{pH} 7.5)$ and then at $75000 \mathrm{~g}$ by discontinuous sucrose density gradient centrifugation $(20-60 \%, w / v)$. The enzyme system, which collected at the interface between $60 \%$ and $40 \%$ sucrose, was used as a source of membrane-bound enzyme (Mukhopadhyay et al. 1985). Labelled dipeptide $\left[\mathrm{U}-{ }^{14} \mathrm{C}\right]$ Pro-Asp, prepared by the amino acid deprivation technique (Sengupta \& Bose, 1972), was then incubated with complementary amino acids for the synthesis of mycobacillin. Recovery of labelled mycobacillin and radioactive counting was as described previously (Majumder et al., 1985).

\section{RESULTS}

\section{Behaviour of $\mathrm{My}^{-}$mutants in whole-cell fermentation and in the cell-free system}

Of the $12 \mathrm{My}^{-}$mutants that were obtained by screening 2200 colonies, three were feeble mycobacillin producers $(\mathrm{N}-47, \mathrm{~N}-43$ and $\mathrm{N}-19)$ whereas the remaining nine were nonproducers $\left(\mathrm{N}-2, \mathrm{~N}-3, \mathrm{~N}-32, \mathrm{~N}-25, \mathrm{~N}-23, \mathrm{~N}-40, \mathrm{~N}-55, \mathrm{~N}-51\right.$ and $\mathrm{N}-48$ ). All the $12 \mathrm{My}^{-}$mutants were $\mathrm{Spo}^{+}$. The degree of sporulation of these $\mathrm{My}^{-}$mutants was similar to that of the wild-type B. subtilis $\mathrm{B}_{3}$ (Majumder et al., 1985).

Culture supernatants from the three feeble antibiotic producers (mutants $\mathrm{N}-47, \mathrm{~N}-43$ and $\mathrm{N}-$ 19) and from five of the strictly $\mathrm{My}^{-}$mutants $(\mathrm{N}-2, \mathrm{~N}-3, \mathrm{~N}-55, \mathrm{~N}-51$ and $\mathrm{N}-48)$ contained no ninhydrin-positive material other than arginine and glutamic acid, used initially in the broth. Culture supernatants from the remaining four strictly $\mathrm{My}^{-}$mutants $(\mathrm{N}-32, \mathrm{~N}-25, \mathrm{~N}-23$ and $\mathrm{N}-$ 40) each contained only one peptide, designated MXI, MXII, MXIII and MXIV, respectively.

The cell-free systems from the four strictly $\mathrm{My}^{-}$mutants $\mathrm{N}-32, \mathrm{~N}-25, \mathrm{~N}-23$ and $\mathrm{N}-40$ each synthesized only one peptide, while the three feeble antibiotic producers $(\mathrm{N}-47, \mathrm{~N}-43$ and $\mathrm{N}-19)$, the auxotrophic parent $\mathrm{A}-1$ and the wild-type $B$. subtilis $\mathrm{B}_{3}$ produced mycobacillin only. Although the two strictly $\mathrm{My}^{-}$mutants $\mathrm{N}-2$ and $\mathrm{N}-3$ did not accumulate any peptide in the culture supernatant, they did synthesize a single peptide in the cell-free system. Mutants N-55, $\mathrm{N}-51$ and $\mathrm{N}-48$ failed to synthesize any peptide in the cell-free system. 
Table 1. Amino acid composition and sequence of peptides accumulated in culture broth

\begin{tabular}{|c|c|c|c|c|c|}
\hline \multirow[b]{2}{*}{ Mutant } & \multicolumn{3}{|c|}{$R_{F}$ values of peptide } & \multirow[b]{2}{*}{$\begin{array}{l}\text { Molar proportion of } \\
\text { amino acids }\end{array}$} & \multirow[b]{2}{*}{ Amino acid sequence } \\
\hline & Peptide & $\begin{array}{c}\text { 1-Butanol/acetic } \\
\text { acid/water } \\
(4: 1: 1 \text {, by vol. })\end{array}$ & $\begin{array}{c}\text { Phenol/water } \\
(3: 1, w / w)\end{array}$ & & \\
\hline $\mathrm{N}-32$ & MXI & $0 \cdot 61$ & 0.69 & Pro $_{1}$, Asp $_{2}$, Glu $_{1}$, Tyr $_{1}$ & Pro $\rightarrow$ Asp $\rightarrow$ Glu $\rightarrow$ Tyr $\rightarrow$ Asp \\
\hline $\mathrm{N}-25$ & MXII & 0.61 & 0.69 & Pro $_{1}$, Asp $_{2}$, Glu $_{1}$, Tyr $_{1}$ & Pro $\rightarrow$ Asp $\rightarrow$ Glu $\rightarrow$ Tyr $\rightarrow$ Asp \\
\hline $\mathrm{N}-23$ & MXIII & 0.61 & $0 \cdot 69$ & Pro $_{1}$, Asp $_{2}$, Glu $_{1}$, Tyr $_{1}$ & Pro $\rightarrow$ Asp $\rightarrow$ Glu $\rightarrow$ Tyr $\rightarrow$ Asp \\
\hline $\mathrm{N}-40$ & MXIV & $0 \cdot 65$ & 0.70 & $\begin{array}{l}\operatorname{Pro}_{1}, \mathrm{Asp}_{3}, \mathrm{Glu}_{1}, \mathrm{Tyr}_{2} \text {, } \\
\mathrm{Ser}_{1}, \mathrm{Leu}_{1}\end{array}$ & $\begin{array}{l}\text { Pro } \rightarrow \text { Asp } \rightarrow \text { Glu } \rightarrow \text { Tyr } \rightarrow \text { Asp } \\
\rightarrow \text { Tyr } \rightarrow \text { Ser } \rightarrow \text { Asp } \rightarrow \text { Leu }\end{array}$ \\
\hline
\end{tabular}

\section{Physicochemical characterization of peptides from culture broths and cell-free systems of blocked mutants : amino acid composition, sequence and molecular mass}

Characteristics of peptides MXI, MXII, MXIII and MXIV are summarized in Table 1.

Peptides MXI, MXII and MXIII, produced by mutants N-32, N-25 and N-23, respectively, appeared to be identical as indicated by their $R_{F}$ values and amino acid composition. These peptides contained four mycobacillin amino acids whose molar proportions were the same as those of the equivalent segment of the mycobacillin molecule. Peptide MXIV contained six mycobacillin amino acids whose molar proportions were also similar to those of the equivalent segment of the mycobacillin molecule.

Peptides MXI, MXII and MXIII contained proline as the N-terminal and aspartic acid as the $\mathrm{C}$-terminal residue. Peptide XIV contained proline as the $\mathrm{N}$-terminal and leucine as the $\mathrm{C}$ terminal residue. The peptide synthesized by mutants $\mathrm{N}-32, \mathrm{~N}-25$ and $\mathrm{N}-23$ in the cell-free system contained four mycobacillin amino acids whose molar proportions and $\mathrm{N}$ - and $\mathrm{C}$ terminal residue were similar to those of MXI, MXII and MXIII. The peptide produced by mutant $\mathrm{N}-40$ in the cell-free system was also similar to MXIV in respect of amino acid composition and $\mathrm{N}$ - and $\mathrm{C}$-terminal amino acids. The peptide which was only obtained from the cell-free system, but was not present in the whole-cell culture broth of mutants $\mathrm{N}-2$ and $\mathrm{N}-3$, contained three mycobacillin amino acids whose molar proportions, $\mathrm{N}$ - and $\mathrm{C}$-terminal residues were also similar to those of the equivalent segment of the mycobacillin molecule.

From a knowledge of the sequence of the first three amino acids, the C-terminal amino acid, the molecular mass and the molar proportions of the constituent amino acids of the peptides MXI/MXII/MXIII, their sequences were determined. They were identical to each other, and similar to that of the pentapeptide MI/MIV/MVIII/MX reported earlier (Majumder et al., 1985). The amino acid sequence of the peptide MXIV was similarly determined from a knowledge of the amino acid sequence of the first seven amino acids, the C-terminal amino acid, the molecular mass and the molar proportions of its constituent amino acids; it was found to be a nonapeptide having the sequence $\mathrm{Pro} \rightarrow \mathrm{Asp} \rightarrow \mathrm{Glu} \rightarrow \mathrm{Tyr} \rightarrow \mathrm{Asp} \rightarrow \mathrm{Tyr} \rightarrow \mathrm{Ser} \rightarrow \mathrm{Asp} \rightarrow$ Leu. Mutants N-2 and N-3 accumulated a three-amino-acid peptide in the cell-free system only. The C-terminal amino acid of this peptide was glutamic acid and the sequence of first two amino acid residues was Pro $\rightarrow$ Asp. Hence the sequence is Pro $\rightarrow$ Asp $\rightarrow$ Glu.

\section{Characterization of the enzymic lesions in the mutant enzyme fractions by in vitro reconstitution experiments and $A T P \rightleftharpoons P_{\mathrm{i}}$ exchange reactions}

The results of enzymic biosynthesis of mycobacillin in which the mutant and wild-type enzyme fractions (Ghosh et al., 1983) were mixed in various combinations indicated that three mutants, $\mathrm{N}-32, \mathrm{~N}-25$ and $\mathrm{N}-23$, had a defect in fraction $\mathrm{B}$ of the mycobacillin-synthesizing enzyme. Mutant $\mathrm{N}-40$, which produced a nonapeptide, had a defect in fraction $\mathrm{C}$ of the enzyme. Mutants N-2 and N-3, which produced a tripeptide in the cell-free system only, had a defect in fraction $A$ of the enzyme. The three mutants $\mathrm{N}-55, \mathrm{~N}-51$ and $\mathrm{N}-48$, which did not produce any peptide in culture broth or in the cell-free system, also had a defect in enzyme fraction A. 


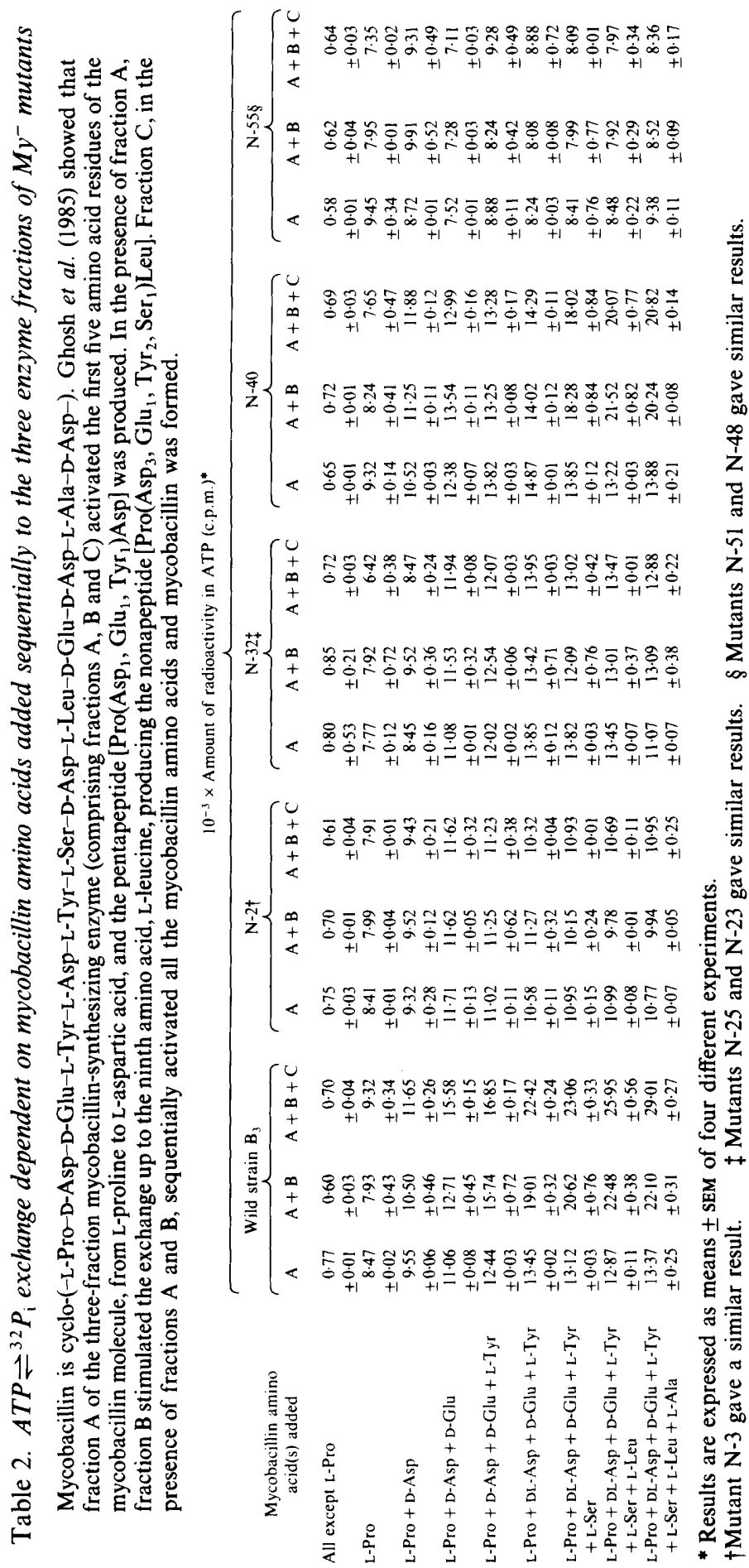


Table 3. Incorporation of labelled peptide $\left(\left[U-{ }^{14} C\right]\right.$ Pro-Asp) into mycobacillin using the membrane-bound particulate form of the mycobacillin-synthesizing enzyme of wild-type and mutant strains

The results are from a single representative experiment.

\begin{tabular}{|c|c|c|c|c|}
\hline Strain & $\begin{array}{l}\text { Radioactivity of } \\
\text { added peptide } \\
\text { (c.p.m.) }\end{array}$ & $\begin{array}{l}\text { Complementary } \\
\text { amino acids } \\
\text { added }\end{array}$ & $\begin{array}{l}\text { Radioactivity } \\
\text { incorporated into } \\
\text { mycobacillin } \\
\text { (c.p.m.) }\end{array}$ & $\begin{array}{c}\text { Incorporation } \\
(\%)\end{array}$ \\
\hline$B_{3}$ (wild-type) & 6517 & $\begin{array}{l}\text { DL-Asp, D-Glu, L-Tyr, } \\
\text { L-Ser, L-Leu, L-Ala }\end{array}$ & 890 & $13 \cdot 6$ \\
\hline N-55 & 6322 & $\begin{array}{l}\text { DL-Asp, D-Glu, L-Tyr, } \\
\text { L-Ser, L-Leu, L-Ala }\end{array}$ & 882 & 13.9 \\
\hline N-51 & 6528 & $\begin{array}{l}\text { DL-Asp, D-Glu, L-Tyr, } \\
\text { L-Ser, L-Leu, L-Ala }\end{array}$ & 888 & $13 \cdot 6$ \\
\hline $\mathrm{N}-48$ & 6504 & $\begin{array}{l}\text { DL-Asp, D-Glu, L-Tyr, } \\
\text { L-Ser, L-Leu, L-Ala }\end{array}$ & 895 & $13 \cdot 7$ \\
\hline
\end{tabular}

The ATP $\rightleftharpoons P_{i}$ exchange dependent on mycobacillin amino acids by different combinations of fractions $\mathrm{A}, \mathrm{B}$ and $\mathrm{C}$ of the mycobacillin-synthesizing enzyme prepared from each of the nine strictly $\mathrm{My}^{-}$mutants (N-2, N-3, N-32, N-25, N-23, N-40, N-55, N-51 and $\mathrm{N}-48$ ) was measured to pin-point the exact location of the defect (Table 2). In the case of mutants $\mathrm{N}-2$ and $\mathrm{N}-3$, which produced a tripeptide, the exchange reaction was sequentially stimulated up to Dglutamic acid, but there was no further stimulation when the next amino acid in the sequence, tyrosine, was added (Table 2). Hence the defect in these mutants is intrafractional, occurring after D-glutamic acid. In the case of mutants $\mathrm{N}-32, \mathrm{~N}-25$ and $\mathrm{N}-23$, which formed the pentapeptide, and have a defect in enzyme fraction $B$, the amino-acid-dependent ATP $\rightleftharpoons P_{i}$ exchange reaction showed that the defect lies at the initiating site of fraction $\mathbf{B}$ (Table 2). In mutant $\mathrm{N}-40$, which formed the nonapeptide, the enzymic lesion in fraction $\mathrm{C}$ was similarly shown to lie at the initiating site of fraction $\mathrm{C}$ (Table 2). The three mutants $\mathrm{N}-55, \mathrm{~N}-51$ and $\mathrm{N}$ 48 , which produced no peptide, either in the culture broth or in the cell-free system, have defects in enzyme fraction $A$. In these mutants, no stimulation of $A T P \rightleftharpoons P_{i}$ exchange activity occurred after L-proline in the presence of mycobacillin amino acids added sequentially (Table 2).

\section{Confirmation of the enzymic lesions by cell-free synthesis}

The membrane-bound particulate enzyme, which recognizes peptides of any chain length for mycobacillin synthesis (unpublished results) was obtained from mutants $\mathrm{N}-55, \mathrm{~N}-51$ and N-48. All these enzyme preparations synthesized labelled mycobacillin in the presence of labelled dipeptide $\left[\mathrm{U}-{ }^{14} \mathrm{C}\right]$ Pro-Asp and complementary mycobacillin amino acids. This showed that the lesion in fraction $A$ of the enzyme is probably after L-proline activation in all these cases (Table 3).

\section{DISCUSSION}

In view of the difference between the mode of biosynthesis of mycobacillin and that of other antibiotic peptides (see Introduction), it should be possible to use the gene-block techniques to isolate mutants that accumulate intermediate peptides of varying chain length, which can be fitted into a plausible biosynthetic scheme for mycobacillin synthesis. In contrast to our earlier work, when we reported the isolation of only one intermediate, a pentapeptide Pro $\rightarrow \mathrm{Asp} \rightarrow \mathrm{Glu} \rightarrow$ $\mathrm{Tyr} \rightarrow \mathrm{Asp}$, from $\mathrm{My}^{-}$mutants (Majumder et al., 1985), further analysis of the culture broths of $\mathrm{My}^{-}$mutants has shown the presence of a new intermediate nonapeptide. No other peptides were obtained in the culture broths. In confirmation of these findings, we have also isolated the penta- and nonapeptides from a cell-free system prepared from these blocked mutants. The sequences of the penta- and nonapeptides correspond to those of the equivalent segments of the mycobacillin molecule. Interestingly, we also isolated from the cell-free system a tripeptide whose amino acid sequence also corresponded to that of a segment of the mycobacillin 
molecule. All the peptides so far discovered can be accounted for if it is assumed that mycobacillin synthesis starts with proline and is interrupted at various points thereafter.

The enzymic lesions causing interruptions in mycobacillin synthesis were characterized by in vitro reconstitution experiments, as well as by an $\mathrm{ATP} \rightleftharpoons \mathrm{P}_{\mathrm{i}}$ exchange reaction, which explained the genesis of the above intermediate peptides. The formation of the tripeptide was due to a defect in enzyme fraction $A$, the lesion being intra-fractional, occurring after the formation of the tripeptide. We do not know why the tripeptide was not found in the culture broth. Our in vitro studies (Sengupta \& Bose, 1972) indicate that intermediate peptides are non-covalently bound to the enzyme, being released either normally on completion of the molecule, or artificially by appropriate treatment, e.g. with n-butanol, at any time before completion. It is possible that the tripeptide is not normally released from the enzyme bed. Alternatively, it may be destroyed if it is released. In mutants that accumulate the pentapeptide, fraction $\mathrm{A}$ is normal. The defect lies at the initiating site of fraction $\mathrm{B}$, as indicated by the $\mathrm{ATP} \rightleftharpoons \mathrm{P}_{\mathrm{i}}$ exchange reaction and also the in vitro reconstitution experiments. Similarly, mutants that accumulate the nonapeptide have a defect at the initiating site of fraction $\mathrm{C}$.

Some mutants did not produce any peptide, either in culture broth or in the cell-free system by the reconstitution test. They showed the ATP $\rightleftharpoons P_{i}$ exchange reaction only with proline, and hence their enzymic lesion presumably lies in fraction A, after activation of L-proline. This was further confirmed by cell-free synthesis, using the membrane-bound, particulate mycobacillinsynthesizing enzyme, which recognized not only preformed peptides of any chain length but also incoming complementary mycobacillin amino acids (unpublished results). Full mycobacillin synthesis was restored to the membrane-bound particulate enzyme preparations from these peptide-negative mutants in the presence of dipeptide $\left[\mathrm{U}-{ }^{14} \mathrm{C}\right]$ Pro-Asp and complementary amino acids.

It is perhaps surprising that although mutants producing tri-, penta- and nonapeptides were obtained, mutants producing other peptides were not. In the formation of the penta- and nonapeptides the enzymic lesion has been pin-pointed at the initiating site, while in the formation of the tripeptide the enzymic lesion is intrafractional for the enzyme fraction $\mathrm{A}$. It would appear from these studies that the defects occur mostly at the initiation sites of the three enzyme fractions of the mycobacillin-synthesizing enzyme. Incomplete intermediate peptides, due to intrafractional defects in any of the three enzyme fractions, might remain bound to the enzyme bed. This might account for the frequent occurrence of complete intermediate nona- and pentapeptides and the rare occurrence of incomplete intermediate peptides like the tripeptide reported here.

Ghosh et al. (1985) fractionated the mycobacillin-synthesizing enzyme into three fractions (A, $B$ and C), all of which are necessary for the in vitro synthesis of mycobacillin from its constituent amino acids. Fraction A of the enzyme synthesizes pentapeptide, fraction B synthesizes the nonapeptide in the presence of pentapeptide and complementary amino acids, and fraction $\mathrm{C}$ synthesizes mycobacillin in the presence of nonapeptide and complementary amino acids. Thus, the present findings using $\mathrm{My}^{-}$mutants entirely agree with those obtained by cell-free synthesis using wild-type enzyme fractions.

Thus studies involving peptide accumulation, and cell-free synthesis using the soluble cytosol enzyme and the membrane-bound particulate enzyme, finally confirm that the tri-, penta- and nonapeptides are all intermediates in mycobacillin biosynthesis, and suggest that all the $\mathrm{My}^{-}$ mutants studied here are structural gene mutants.

\section{REFERENCES}

Banerjee, A. B. \& Bose, S. K. (1964). A rapid method for isolating mutants of Bacillus subtilis producing increased or decreased amounts of the antibiotic, mycobacillin. Journal of Applied Bacteriology 27, 9395.

Bredesen, J. E., Zimmer, T. L. \& Laland, S. G. (1969). Starting point and direction of biosynthesis of gramicidin S. FEBS Letters 3, 169-172.
Ghosh, S. K., Mukhopadhyay, N. K., Majumder, S. \& Bose, S. K. (1983). Fractionation of the mycobacillin synthesizing enzyme system. Biochemical Journal 215, 539-543.

Ghosh, S. K., Majumder, S., Mukhopadhyay, N. K. \& Bose, S. K. (1985). Functional characterization of constituent enzyme fractions of mycobacillin synthetase. Biochemical Journal 230, 785-789. 
Hori, K., Kanda, M., Kurotsu, T., Miura, S. YamadA, Y. \& SAITo, Y. (1981). Absence of pantothenic acid in gramicidin $\mathrm{S}$ synthetase obtained from some mutants of Bacillus brevis. Journal of Biochemistry 90, 439-447.

Itoh, H., Yamada, M., Tomino, S. \& Kurahashi, K. (1968). The role of two complementary fractions of gramicidin S synthesizing enzyme system. Journal of Biochemistry 64, 259-261.

Kambe, M., Imae, Y. \& Kurahashi, K. (1974). Biochemical studies on gramicidin S non-producing mutants of Bacillus brevis ATCC 9999. Journal of Biochemistry 75, 481-493.

Majumder, S., Ghosh, S. K., Mukhopadhyay, N. K. \& Bose, S. K. (1985). Accumulation of peptides of mycobacillin-negative mutants of Bacillus subtilis $\mathrm{B}_{3}$. Journal of General Microbiology 131, 119-127.
Mukhopadhyay, N. K., Ghosh, S. K. Mujumder, S \& Bose, S. K. (1985). Translocation of mycobacillin synthetase in Bacillus subtilis. Biochemical Journal 225, 639-643.

Mukhopadhyay, N. K., Majumder, S., Ghosh, S. K \& BosE, S. K. (1986). Characterization of threefraction mycobacillin synthetase. Biochemical Journal 235, 639-643.

Sengupta, S. \& Bose, S. K. (1972). Peptides from a mycobacillin synthesizing cell-free system. Biochemical Journal 128, 47-52.

StulberG, M. P. \& Novelli, G. D. (1962). Amino acid-activating enzymes: methods of assay. Methods in Enzymology, 5, 703-707. 